Uji potensi antiplasmodium ekstrak buah pare... (Susilawati dan Hermansyah)

\title{
UJI POTENSI ANTIPLASMODIUM EKSTRAK BUAH PARE (Momordica charantia L.) TERHADAP Plasmodium falcifarum
}

\section{TEST POTENTIAL OF FRUIT EXTRACT ANTIPLASMODIUM PARE (Momordica charantia L.) ON Plasmodium falcifarum}

\author{
Susilawati dan Hermansyah* \\ Fakultas Kedokteran Universitas Sriwijaya \\ Jurusan Kimia FMIPA Universitas Sriwijaya \\ *email : susilwt78@yahoo.com
}

\begin{abstract}
ABSTRAK
Malaria masih menjadi salah satu penyakit endemis dan masalah kesehatan utama di Indonesia. Buah pare (Momordica charantia L.) secara tradisional sering digunakan sebagai obat. Tujuan dari penelitian ini adalah untuk menguji potensi antiplasmodium in vitro ekstrak buah pare terhadap Palsmodium falciparum sehingga dapat digunakan sebagai obat anti malaria. Buah pare diekstrak dengan metode maserasi menggunakan pelarut metanol. Uji aktivitas antiplasmodium dilakukan secara pengamatan mikroskopik pada kultur strain $P$. falcifarum 3D7. Berdasarkan hasil pengujian, sampel ekstrak metanol buah pare memiliki aktivitas penghambatan terhadap pertumbuhan parasit $P$. falciparum 3D7. Kekuatan aktivitas antimalaria dengan nilai $\mathrm{IC}_{50}=0,39 \mu \mathrm{g} / \mathrm{mL}$.
\end{abstract}

Kata kunci : Malaria, Momordica charantia L., Antiplasmodium.

\begin{abstract}
Malaria is one of the most common endemic disease and the major health issues in Indonesia. Momordica charantia L. (bitter melon fruit) is traditionally used as medicine. The aim of this research is to assay the potency of methanol extract of bitter melon extract in vitro antiplasmodial activity against Palsmodium falciparum. Bitter melon was extracted by macerate method using methanol. Antiplasmodial activity assay was carried out by microscopically observing culture of $P$. falcifarum 3D7 strain. Based upon the results research, methanol extract of bitter melon inhibited the growth of $P$. falciparum 3D7. The strength activity of antiplasmodial of methanol extract of bitter melon was with $\mathrm{IC}_{50}=0,39 \mu \mathrm{g} / \mathrm{mL}$.
\end{abstract}

Keywords : Malaria, Momordica charantia L, Antiplasmodium.

\section{PENDAHULUAN}

Malaria adalah penyakit infeksi dengan demam berkala yang disebabkan oleh parasit Plasmodium dan dapat ditularkan oleh nyamuk tertentu (Anopheles). Berbeda dengan nyamuk biasa (Culex), nyamuk ini khususnya menyengat pada malam hari dengan posisi yang khas, yaitu bagian belakangnya mengarah ke atas dengan sudut $48^{\circ} \mathrm{C}$ (Tjai dan Rahardja, 2002). Penyakit malaria merupakan penyakit yang banyak terdapat didaerah yang beriklim panas dan lembab seperti Indonesia dengan tingkat mortalitas $1 \%$. Di Indonesia, malaria merupakan penyakit endemis penting yang harus di 
tangani secara serius. Data WHO tahun 2005 menyebutkan bahwa terdapat 433.326 kasus dari 232 juta penduduk Indonesia (WHO, 2007).

Buah pare sangat populer di Indonesia terbukti banyak nama lokalnya misalnya di Jawa dikenal dengan nama paria atau pare; di Sumatera dikenal dengan prieu, fori, pepare, kambeh, pare; di Nusa Tenggara disebut dengan paya, truwuk, paitap, paliak, pariak, pania, dan pepule; sedangkan di Sulawesi disebut poya, pudu, pentum palia. Beberapa penelitian telah mengeksplorasi tentang kandungan senyawa kimia dalam buah yang memiliki aktifitas biologi. Senyawa-senyawa tersebut adalah momordicin, cucurbitacin, glycosida, charantin, charantosida, momordicilin, momordicinin, momordol, dan lain lain. Kandungan senyawa kimia ini banyak yang berpotensi sebagai obat-obat, sehingga tidak mengherankan jika buah pare banyak memiliki khasiat sebagai obat bahkan sebagai anti kanker (Rita, dkk, 2008).

Berbagai usaha untuk mengatasi malaria, diantaranya menghindari gigitan nyamuk anopheles, mencegah berkembangnya nyamuk, vaksinasi, hingga pemberian pengobatan pencegahan seperti vaksinasi (Gunawan, 2000). Sebagai obat malaria, sudah banya digunakan dengan berbagai mekanisme. Dari mulai kinin yang merupakan obat tertua dalam mengobati malaria, kloroquin yang lebih ringan efek samping dan memiliki efek kuratif lebih baik, hingga pyronaridin yang sangat efektif terhadap P.falcifarum multiresisten. Salah satu mekanisme obat malaria adalah mencegah kerusakan hemoglobin oleh parasit, sehingga timbul kekurangan asam amino esensial untuk sintesis DNA parasit tersebut (Tjai dan Rahardja, 2002). Asam-asam lemak juga berpotensi menghambat mesin biosintetik asam lemak parasit
P.falcifarum (Melariri et al., 2012). Tujuan dari penelitian ini adalah menguji aktivitas antiplasmodium dari ekstrak metanol buah pare terhadap $P$. falcifarum strain dengan menentukan nilai $\mathrm{IC}_{50}$ nya. Hasil penelitian ini diharapkan dapat memberikan informasi kepada masyarakat tentang kegunaan dari buah pare yang dapat digunakan sebagai pencegahan maupun pengobatan malaria. Penggunaan obat-obat herbal akan mengurangi ketergantungan terhadap obat sintesis yang sering memiliki berbagai efek samping.

\section{METODE PENELITIAN}

\section{Alat dan Bahan}

$P$. falciparum strain 3D7, buah pare (Momordica charantia L.) yang tua yang dibeli di pasar tradisonal KM5 Palembang, metanol, DMSO, RPMI, eritrosit, pewarna Giemsa.

\section{Prosedur Penelitian}

Persiapan ekstrak methanol buah pare dilakukan di laboratorium Biokimia FMIPA Universitas Sriwijaya, sedangkan pengujian aktivitas antiplasmodium dilakukan di Herbal medicine research group Fakultas Farmasi Universitas Airlangga.

Persiapan sampel : Sebanyak $10 \mathrm{~kg}$ buah pare (M. charantia L) yang dibeli dari pasar KM5 dibersihkan dari kontaminasi lain, dicuci, dipotong kecilkecil ukuran $1 \mathrm{~cm}$, dan dikeringkan dengan cara diangin-anginkan untuk menghilangkan kadar air hingga didapat berat konstan. Selanjutnya dihaluskan dengan grinder dan diayak hingga berukuran 100 mesh.

\section{Pembuatan ekstrak metanol buah pare secara maserasi}

Lima ratus gram serbuk kering buah pare $(M$. charantia L) dimaserasi dengan $1000 \mathrm{ml}$ metanol selama 24 jam, sambil diaduk-aduk secara berkala, 
disaring menggunakan kertas saring kasar. Ampas sisa dimaserasi lagi 3 kali supaya semua zat yang terkandung dalam buah pare tersebut terekstrak. Semua filtrat yang selanjutnya dikumpulkan dan dievaporasi pelarut metanol hingga didapat ekstrak buah pare.

\section{Persiapan larutan uji yang mengandung ekstrak buah pare}

Buat larutan stok dengan konsentrasi $25 \mathrm{mg} / \mathrm{ml}$ dengan cara melarutkan sebanyak $5 \mathrm{mg}$ ekstrak buah pare ke dalam DMSO sampai volume $200 \mu \mathrm{l}$. Larutan stok kemudian diencerkan hingga didapat konsentrasi $0,5 \mu \mathrm{g} / \mathrm{ml}$ dengan cara mengencerkannya menggunakan media RPMI ( Roswell Park Memorial Institute ) 1640

\section{Uji in vitro antiplasmodium terhadap} $P$. falcifarum

Pada uji aktivitas antimalaria in vitro digunakan $P$. falciparum strain 3D7 yang sensitif terhadap klorokuin. Uji aktivitas dilakukan dengan cara melarutkan bahan uji dalam DMSO kemudian dibuat serial pengenceran dalam media RPMI sampai diperoleh konsentrasi akhir sebesar $100 \mu \mathrm{g} / \mathrm{ml}, 10$ $\mu \mathrm{g} / \mathrm{ml}, \quad 1 \mu \mathrm{g} / \mathrm{ml}, \quad 0,1 \mu \mathrm{g} / \mathrm{ml}$ dan 0,01 $\mu \mathrm{g} / \mathrm{ml}$. Pada larutan uji ditambahkan suspensi parasit dengan kadar parasit $1 \%$ dan hematokrit 5\%. Kultur diinkubasi selama 48 jam pada suhu $37^{\circ} \mathrm{C}$. Kultur kemudian dipanen dan dibuat sediaan lapisan darah tipis dengan pewarnaan giemsa $20 \%$. Selanjutnya dihitung persen parasit dan persen penghambatan pertumbuhan $P$. falciparum dengan menghitung jumlah eritrosit yang terinfeksi setiap 5000 eritrosit di bawah mikroskop. Sebagai konrol negatif digunakan media saja tanpa penambahan bahan uji (ekstrak buah pare).

Persen pertumbuhan didapatkan dengan menggunakan rumus sebagai berikut:
$\%$ pertumbuhan $=\%$ parasit $-\mathrm{D} 0$

Keterangan:

$\mathrm{D} 0=\%$ pertumbuhan parasit pada jam ke-0

Rumus untuk perhitungan \% penghambatan adalah sebagai berikut :

Persen penghambatan

$$
=100 \%-((\mathrm{Xu} / \mathrm{Xk}) \times 100 \%)
$$

\section{Keterangan:}

$\mathrm{Xu}=\%$ pertumbuhan pada larutan uji

$\mathrm{Xk}=\%$ pertumbuhan pada kontrol negatif

Berdasarkan data persen penghambatan dilakukan analisis antara konsentrasi uji terhadap persen penghambatan dengan menggunakan analisis probit log untuk mengetahui nilai $\mathrm{IC}_{50}$ atau konsentrasi bahan uji yang dapat menghambat pertumbuhan parasit sebanyak 50\%.

\section{HASIL DAN PEMBAHASAN}

Buah pare yang telah diekstrak dengan metanol, kemudian dilakukan evaporasi metanol sehingga didapatkan ekstrak methanol buah Pare siap dilakukan uji antiplasmodium terhadap

P. falciparum 3D7. Persentase pertumbuhan parasit dan persen penghambatan ekstrak metanol buah Pare terhadap $P$. falciparum 3D7 dapat dilihat pada Tabel 1. Berdasarkan hasil pengujian, sampel ekstrak metanol buah pare memiliki aktivitas penghambatan terhadap pertumbuhan parasit $P$. falciparum 3D7. Kekuatan aktivitas antimalaria dengan nilai $\mathrm{IC}_{50}=0,39$ $\mu \mathrm{g} / \mathrm{mL}$. Sedangkan, menurut Fidock et al (2004), obat (senyawa murni) prospektif untuk antimalaria : nilai $\mathrm{IC}_{50}$ $<1-5 \mu \mathrm{M}$ pada uji antimalaria in vitro. Kohler et al. (2002) : ekstrak dengan nilai $\mathrm{IC}_{50}<50 \mu \mathrm{g} / \mathrm{ml}$ dan fraksi dengan nilai $\mathrm{IC}_{50}<25 \mu \mathrm{g} / \mathrm{ml}$ efektif sebagai 
antimalaria. Ektrak buah pare memiliki nilai $\mathrm{IC}_{50}$ yang lebih kecil jika dibandingkan dengan nilai $\mathrm{IC}_{50}$ daun kembang bulan. Syarif dkk (2012) yang melakukan penelitian terhadap daun kembang bulan (Tithonia diversifolia
(Hemsey) A. Gray) dengan memberikan nilai IC50 sebesar 8,12 $\pm 0,53 \mu \mathrm{g} / \mathrm{ml}$. Berdasarkan hasil ini Ekstrak buah pare memiliki aktivitas antiplasmodium lebih baik.

Tabel 1. Persen pertumbuhan parasit dan persen penghambatan ekstrak metanol buah Pare terhadap Plasmodium falciparum 3D7

\begin{tabular}{ccccccc}
\hline $\begin{array}{c}\text { Konsentrasi } \\
(\mu \mathrm{g} / \mathrm{ml})\end{array}$ & $\mathrm{R}$ & 0 jam & 48 jam & \% Pertumbuhan & \% Hambatan & $\begin{array}{c}\% \\
\text { Hambatan } \\
\text { rata-rata }\end{array}$ \\
\hline \multirow{2}{*}{ Kontrol (-) } & 1 & 1,06 & 3,97 & 2,91 & - & - \\
& 2 & 1,06 & 4,05 & 2,99 & - & \\
\multirow{2}{*}{100} & 1 & 1,06 & 1,29 & 0,23 & 92,09 & 91,37 \\
& 2 & 1,06 & 1,34 & 0,28 & 90,64 & \\
10 & 1 & 1,06 & 1,72 & 0,66 & 77,32 & 76,95 \\
& 2 & 1,06 & 1,76 & 0,70 & 76,59 & \\
1 & 1 & 1,06 & 2,34 & 1,28 & 56,01 & 55,76 \\
& 2 & 1,06 & 2,39 & 1,33 & 55,52 & \\
0,1 & 1 & 1,06 & 2,80 & 1,74 & 40,21 & 40,00 \\
0,01 & 2 & 1,06 & 2,86 & 1,80 & 39,80 & \\
& 1 & 1,06 & 3,41 & 2,35 & 19,24 & 19,32 \\
& 2 & 1,06 & 3,47 & 2,41 & 19,40 & \\
\hline
\end{tabular}

\section{KESIMPULAN}

Kesimpulan :

1. Ekstrak kasar buah pare telah berhasil diektrak dengan menggunakan pelarut metanol.

2. Berdasarkan hasil pengujian, sampel ekstrak metanol buah pare memiliki aktivitas penghambatan terhadap pertumbuhan parasit Plasmodium falciparum 3D7. Kekuatan aktivitas antimalaria dengan nilai $\mathrm{IC}_{50}=0,39 \mu \mathrm{g} / \mathrm{mL}$.

Saran :

1. Perlu dilakukan fraksinasi dan pemurnian untuk mendapatkan senyawa aktif yang terdapat dalam buah Pare sebagai obat malaria.
2. Perlu dilakukan uji antiplasmodium terhadap strain yang resisten terhadap obat malaria yang sering dipakai misalnya resisten terhadap Kloroquin.

\section{DAFTAR PUSTAKA}

Fidock,D A., Rosenthal, P J., Croft, S L., Brun, R., Nwaka, S., 2004, Antimalarial drug discovery: efficacy models for compound screening, Nature Reviews Drug Discovery. 3, 509-520.

Gunawan, S. 2000. Epidemiologi Malaria (in) P.N. Harijanto. (ed): Malaria, Epidemiologi, Patogenesis, manifestasi Klinis 
Uji potensi antiplasmodium ekstrak buah pare... (Susilawati dan Hermansyah)

dan Penanganan. EGC. Penerbit Buku Kedokteran. Jakarta.1-13.

Kohler, I. et. al., 2002. In Vitro Antiplasmodial Investigation of Medicinal Plants from El Savador. Z. Naturforsch. 57c, 277-278.

Melariri, P., Campbell, W., Etusim, P., and Smith, P., 2012, In vitro and in vivo antimalarial activity of linolenic and linoleic acids and their methyl esters, Advanced Studies in Biology, Vol. 4:7, 333349.

Rita, W.S., Suirta, I.W., and Sabikin, A., 2008, Isolasi dan Identifikasi senyawa yang berpotensi sebagai antitumor pada daging buah pare (Momordica charantia L.), Jurnal Kimia; 2;1-6.
Syarif, R.A., Wahyuningsih, M.S.H., Mustofa, Ngatijan, Kurniawan, H., dan Al Hilal, S.R, 2012, Aktivitas antiplasmodium in vitro ekstrak kembang bulan (Tithonia diversifolia (Hemsley) A.Gray) terhadap Plasmodium falcifarum, http://dosen.narotama.ac.id/wpcontent/uploads/2012/02/ diakses pada 3 Desember 2012.

Tjay, T.H. dan Rahardja, K., 2002, Obat-obat penting: Khasiat, penggunaan, dan efek-efek sampingnya. Penerbit PT. Elex Media Komputindo Gramedia, Jakarta.

WHO, 2007, Malaria situation in SEAR countries : Indonesia in Malaria. WHO. Regioal office for South East Asia. Last updated: 27 Februari 2007. 